\title{
FROM NATURE ROMANTICISM TO ECO- NATIONALISM: THE DEVELOPMENT OF THE CONCEPT OF ESTONIANS AS A FOREST NATION
}

\author{
Atko Remmel \\ PhD, Associate Professor \\ School of Theology and Religious Studies, University of Tartu, Estonia \\ School of Humanities, Tallinn University, Estonia \\ atko.remmel@ut.ee
}

\section{Tõnno Jonuks}

PhD, Research Professor

Estonian Literary Museum, Estonia

Research Fellow

School of Humanities, Tallinn University, Estonia

tonno.jonuks@folklore.ee

\begin{abstract}
Forest plays an important role in many North European national identities. The Estonian example is one of the extreme cases as Estonians consider themselves a forest nation, the claim being backed up with references to both history and contemporary data. The article explores diachronically the formation of this motif in the Estonian national narrative and studies the nuances of intellectual and social history that have shaped the development of the concept from ethnic nature to eco-nationalism.
\end{abstract}

Keywords: eco-nationalism, Estonia, ethnic nature, forest nation, national identity, national narrative

Estonians and their relatives the Livonians did not live scattered in the woods like their neighbours the Latvians. Instead, they had villages and towns, to which the power of the enemy could do no harm for a long time. (Jakobson 1991 [1868]: 17)

As the most prevalent landscape in Estonia has most likely been the forest, the title 'forest nation' suits quite nicely. ... Since there are fewer forest peoples in the world than indigenous peoples (some nations are instead 
connected with the ocean, the mountains or the deserts), then a crucial mission falls to Estonian culture: to preserve the invaluable relationship with the forest and the land. (Mikita 2015: 19)

National narratives provide recognisable and consolidative stories, which form a basis for the creation and preservation of national identities. Coakley (2004) identifies three types of national narrative: a) related to origin, b) related to development (through the Golden Age, Dark Age and Age of Struggles), and c) related to destiny. In such narratives, the past tends to have a central and legitimising role. During the creation of a myth, suitable details are selected from history and combined into a fitting narrative, depending on the needs of contemporary societies (Annus 2000). Therefore, national narratives are flexible and prone to adaptation. As a result, national narratives include values and assessments from the time the story was created and are therefore more revealing about the periods and contexts of their creation than the periods they claim to describe.

Most of the national narratives are referred to as singular entities, and sometimes a distinction is made between "meta-narratives" and "micro-narratives" (stories about stories) (Auerbach 2009). Yet, especially from the perspective of intellectual history, national myths are bundles of different sub-motifs, which are loosely attached to a backbone, the main incorporating narrative or idea. These sub-motifs have their own origins, high and low points in popularity. They support the main narrative - the unifying paradigm (Morden 2016) - and, simultaneously, are supported by the main narrative itself.

In the Estonian case, the main narrative is about the survival of Estonian culture (Tamm 2008), while sub-motifs surrounding it describe different archetypal 'Estonians': the silent and reticent but devoted farmer Esthonus laborans; the educated and rational Esthonus sapiens; the music-loving Esthonus canens (reappearing before and after the National Singing and Dancing Festival every four years); the submissive Esthonus servus, and his brother, the peace-loving Esthonus pacificans, both of whom suffer under mighty landlords; and their distant relative, Esthonus bellator, who ruled the Baltic Sea in ancient times. Among these, there is also a nature-loving Esthonus silvanus, the forest Estonian, protagonist of this article.

The quotes provided at the beginning of this article illustrate the evolution of Esthonus silvanus over 150 years: from the romantic longing for the golden past to contemporary eco-nationalism. The rise of eco-nationalism - the idea of the endurance of national culture as connected with the preservation of the 
local natural environment - has been associated with the developments of the late Soviet period (Dawson 1996; Malloy 2009). Diachronic analysis of the Esthonus silvanus trope indicates that the idea of eco-nationalism resonates across a much longer time, although the exact narrative of the forest Estonian was indeed formed in the past few decades. The article focuses on how this motif was historically formed and what circumstances affected its development. The length of the article does not allow us to give a comprehensive overview - the article is rather a condensed sketch that offers first glimpses into the process of eco-national myth-making.

\section{SOURCES}

The selection of sources for the study of the Estonian national narrative is problematic as the topics it covers, their boundaries and spread, are vague. First of all, there is a question: when does a narrative become national? Is it when a certain bundle of ideas spread among the intelligentsia, while its members - writers and composers or scholars - may purposefully contribute to the development of the narrative? Or is it when the motifs of the national narrative appear unconsciously in popular science articles, schoolbooks, and fiction, where the construction of the national story is not a primary goal and national narrative is used to achieve other objectives? The situation is even more vague, since occasionally the national narrative has even been applied to pre-existing works due to their later interpretations. Secondly, the genres that are important for the spread of national ideas vary in relevance throughout different eras. During the nineteenth century, journalism played an important role in spreading national ideas (Peegel et al. 1994: 44-46). The importance of textbooks in the development of a nation should also be noted, whilst fiction, music, and art exerted a more prevalent influence especially in the field of ecological thinking during the Soviet era (Dronin \& Francis 2018).

Considering the above, we decided to trace the emergence of the bundle of ideas that interests us in different genres, which is the best indicator of their spread: from popular science to scientific literature, from schoolbooks to literature related to tourism and forestation management. The main criterion for the selection was a (possible) relationship with nature and the Estonian identity. This list is definitely not exhaustive as the inclusion of other media such as art, music, and film can give more detailed - and perhaps alternative insights into the development of the Estonian national myth and the evolution of Esthonus silvanus. 


\section{ENLIGHTENERS, ROMANTICS, AND AWAKENERS}

The nineteenth century, the era of "inventing traditions" (Hobsbawm \& Ranger 1992 [1983]), also gave birth to the Estonian nation as an "imagined community" (Anderson 2016 [1983]). Since the Middle Ages, Estonia had been governed by different foreign nations so that by the nineteenth century the local elite consisted mainly of a German-speaking nobility. Estophiles originating from those circles were the first to be interested in the heritage of locals and to identify Estonians and Latvians as nations equal to others. As their source of inspiration was the German context, many of the early motifs of the Estonian national narrative can be traced to their German origins, transferred to the Baltic context (Plath 2008: 39).

Most of the Western European national stories are backed up by written sources. The German national narrative usually begins with the heroic victory of German tribes over the Roman legions in $9 \mathrm{AD}$ as described by Tacitus in Germania. Using the same method, the forefather of the Estonian national myth, Garlieb Helwig Merkel (1798) anchored the story to Henrik's Livonian Chronicle, which depicts the ancient Estonian-Latvian struggle against the Catholic crusaders in the early thirteenth century. In Merkel's narrative, the conquest divided Estonian history in half, with the 'Golden Age' before, followed by aggressive occupation by the greedy Catholic Church.

Merkel's narrative was built on social and religious contradictions, although concepts such as 'nature' and 'wild' also had a significant position. Eighteenthcentury romanticism and sentimentalism gave rise to the ideas of "returning to nature" and "noble savage", which were now imported to the Baltic countries, and attributed to the local residents in the Baltic countries (Plath 2008: 41). However, only the 'pre-crusade' pagan ancestors of the contemporary peasants were considered 'noble' (Jonuks 2009: 20) as Estonians and Latvians after the thirteenth century were considered 'civilised' and lost their contact with nature (Plath 2008: 46). Nevertheless, an echo of their noble savageness was noticed in folk songs, which inspired Herder (1773) to value local song traditions with a sensitivity appropriate to the romantic spirit. This set of ideas about a formerly pristine and noble culture was seized on enthusiastically by the nascent Estonian intelligentsia, who took over the nation-building project in the late nineteenth century (Jansen 2004: 116) and started to create their own national narrative.

In the words of Denis Cosgrove (2003: 16) "the forest has been crucial in framing national identities in most countries north of the Alps". However, due to the lack of sources, it is hard to estimate the importance of nature and the forest to Estonians' self-perception until the end of the nineteenth century. It 
is possible that nature was not in a significant position in self-determination but only in a "supportive role" since the usage of natural resources (e.g. hunting, use of wood and other raw materials) has been a marker of social position and prestige (Varep 1983). The position of nature even for the nobility becomes apparent only from the Enlightenment. The qualitative value of 'wild' nature is most apparent in the tradition of English parks, spreading to Estonia in the late eighteenth century (Hein 2007). This style emphasised natural and romantic elements, groves, grottoes, ruins, and shaped the parks on both rural manors and in towns. Ironically, such parks became the only green oases in the deforested landscape of the late eighteenth and early nineteenth centuries, which suffered from extensive logging:

It is nearly impossible to find oak forests that used to be so common earlier. We no longer have them, we have cut them all down, destroyed them! Only a few stand - here and there - and they too keep on disappearing! Who is considering reforestation? Only a few and even they have only recently embraced the noble idea, but the destruction of forests is on everybody's mind! (Germann 2018 [1803]: 1031)

The wood was needed for the construction of manors and towns, but also for different industries, including distilleries - one of the main sources of wealth for Estonian manors. The disappearance of the forests was also associated with the peasants' love of wooden fences (e.g. Hupel 1777: 104, 488; Friebe 1794), but also with "the habit of our people to clear land for the production of grain by burning trees and underbrush, ... heating the threshing barns to dry the grain and the lavish manner of heating houses" because "the Estonian, who does not think of living in a warm but a hot room, does not consider economising on trees" (Baer 2013 [1814]: 24, 57).

As indicate different proverbs and sayings about nature and forest (FES 2011), in which the motifs of hunting, gathering and practical use of trees dominate, the attitude of Estonian rural population to the forest in the nineteenth century was pragmatic and rational. In metaphorical uses, the forest in folklore appears as neutral or even negative: the forest is a place where one gets lost, it is strange, full of animals and evil spirits. Therefore, many expressions based on mets (forest) refer to negative associations, such as metsa poole (towards the forest = out of one's mind), metslane (savage), mine metsa! (go to the forest $=$ get lost!).

In the literature of the nineteenth century, metaphorical uses of the forest similarly have neutral or negative connotations. Nature, and the forest in particular, is rather insignificant in the national epic Kalevipoeg (Son of Kalev) (Kreutzwald 1862). The scenes with this mythical hero take place on cultural 
landscapes like fields, meadows, etc., with the forest mentioned only in contexts where Kalevipoeg chops it down. His nickname - The Great Ploughman - also characterises the hero as a creator of cultivated landscapes (Eilart 1961), where most of the rural population lived at the time.

Another example of the negative connotations associated with the forest is the usage of the word kõrve (originally 'large uninhabited (swampy) forest') as a translation of 'desert' in the Estonian Bible (Kents 1947: 10-12). In the same vein, the forest was associated with illiteracy and barbarity. Friedrich R. Kreutzwald, the creator of the national epic Kalevipoeg, used the forest as a metaphor for those who are uneducated and uncared-for, the antidote to which is culturalization: "But if we plant a wild forest flower in fertile garden soil and tend to it, then in time it will grow into a beautiful flower outshining its brothers and sisters growing in the meadow" (Kruus 1940: 15). The forest was also considered unhealthy, for instance, by Baer (2013 [1814]: 92): “The forests, which still are too widespread from a medical perspective, are harmful due to the disruption of airflow but especially if there is, as per usual, a lot of rotting wood."

The motif of the forest as strange, unnurtured, and uneducated intertwines with the narrative of historical disruption in the thirteenth century. In C. R. Jakobson's view, the forest represents darkness in the battle between "light" and "dark": "one thousand years ago when many European countries were cloaked in the forests' darkness". Jakobson turns this around: "Truly, this was the Estonian time of light!" Henceforth emerge the anti-German and anticlerical motifs, in which the forest is regarded as a safe haven, especially when describing punishments used for indoctrination of Christianity, due to which "the people often escape from their ministers to the forest". This critical remark, however, does not mean a criticism of Christianity but rather a criticism of the clerical system, as was common in the nineteenth century. Christianity largely formed the model for understanding the world in general at that time. Even the descriptions of the ancient Estonian religion that relied on the trope of disruption, and contrasted "ancient holism" to Christian dualism, actually presented Christian concepts within a framework of prehistoric religion, used Christian language and even referred to the Ten Commandments (Heraklides 1908; see also Laanes 2012: 159).

Although the beginning of the twentieth century is today commonly regarded as the birth of the Estonian nation (phase three in Hroch's (1985) periodisation), the connections between Estonian identity and nature were not topical. Being a socially second-rate ethnic group with rising national consciousness, it was preferable at the time to emphasise the high level of ancient Estonian culture (Laanes 2012: 160). Most references to the forest still represented either 
the utilitarian relationship or described the forest as a strange and dangerous place. Aarelaid and Relve (1980: 98) explained it with the collapse of traditional agrarian society, which regarded nature as an equal partner, replaced now by the 'hireling's attitude', which emphasises only monetary value. Another current describes the forest within the framework of (Neo-)Romanticism, explained by Aarelaid and Relve (1980: 98) as a reaction that opposes urbanisation, where everything urban was considered the root of all evil, while rural life was idealised. Indeed, this idea was straightforwardly put by Eduard Vilde in his comedy Pisuhänd (1913: 52):

Haven't you heard of our latest literary trend? What has a writer to do with the town! What artistic material does he acquire in the town! Who cares about the shallow workings of the townsman! A writer must stay in the village, dear man! Only there can he discover poetry, the big idea; all of our uniqueness lies in the barn and the threshing room!

Thus, during the time when nation and national consciousness were formed, we cannot find a positive image of the forest. An idealisation and exaltation of the forest and the wild is present in (neo-)romantic literature and historical novels, which indeed influenced the first generations of the local intelligentsia and indirectly also Estonian folklore. However, despite the efforts of the romanticist literati, the local peasantry themselves did not use nature or the forest as a cornerstone of their national identity.

\section{ESTONIANS AND NATURE DURING THE INDEPENDENT REPUBLIC OF ESTONIA}

Estonia, like many other nation-states in Eastern Europe, gained statehood after World War I, in 1918. The era of independence in the interwar period brought remarkable changes to Estonian social life and national identity. Now, the national narrative based on two main archetypes - Esthonus laborans, the hardworking Estonian, and Esthonus bellator, the warrior-Estonian who heroically protected his home - combined with Esthonus servus, the Estonian as victim, who had suffered 700 years of enslavement under German rule.

These two archetypes formed a suitable context for the appearance of Esthonus silvanus. Nature provided a background, whereas the real values were the results of hard work - as, for instance, in one of the most influential sources for the Estonian national narrative, A. H. Tammsaare's Tõde ja õigus (Truth and Justice): 
This surviving field here on a faraway swamp island seemed like a fairy tale. It felt strange and homely. It didn't need to be said that someone had moved, worked, and thought here at some point in time. A human's joys and woes had once been connected with this small field. (Tammsaare 1981 [1926]: 12-13)

However, not only writers valued work. Giving a new value to nature has been described as a part of farmers' mindset: "I have been a sad witness to an occasion where an elderly man said after chopping down a beautiful spruce forest that the landscape had now become much more beautiful, everything is now so pretty and bare" (Reim 1940: 98). One should also note here the two-layered discourse, a discordance between the elite's conservationist attitude and an ordinary representative of the nation.

Statehood brought along the most important development in the field of nature and nationality, the concept of ethnic nature, that is, interpreting local nature through a national(ist) perspective, and within the physical borders of the nation-state. Already in the nineteenth-century Germany the forest was considered not only a physical but also a spiritual and cultural entity, forming later into an imagination of an ethnicised forest: "Germans need the forest like man needs wine" (Zechner 2011; see also Imort 2005). This concept would have been impossible in Estonia before the land reform of 1919, which nationalised previous manor lands, after which "Estonians became the masters of their lands and forests once again after 700 years of foreign rule" (Daniel 1929: 21).

The search for identity, especially in the 1920 s, developed by opposing earlier dominances. This happened mainly nationally, against the former upper class, the Germans, but also within religion. The concept of ethnic nature fitted into the schema perfectly as the Estonians' ancient religion was opposed to Christianity (brought by the Germans): "The pagan traditions protected the oak forests before the Germans came. They tried to destroy everything related to paganism. Their anger first hit the sacred groves which were mainly oak forests" (Helm 1924: 62).

This opposition became especially prominent in the rhetoric of the Taara faith (established in 1925), which claimed to be a modern revival of the ethnic religion of Estonians before Christianisation in the thirteenth century: "You cannot serve two gods at the same time: Christ and Estonia. Either you are a good Christian and a bad Estonian, or vice versa" (Hiis 1930a: 14). The followers of Taara faith repeated earlier romanticist claims of ancient Estonians who lived in harmony with their surroundings and tried to show the underlying paganism in contemporary holidays while minimising the impact of Christianity on Estonian culture: "But the traditions of Christmas, which bring us that 
special fragile excitement and jolly mood, are actually 'secular', 'pagan', and therefore 'Taara-ish"' (Hiis 1930b: 26). Yet nature and the forest were secondary in the philosophy of the Taara faith, mainly appearing as metaphors - their ideal was cultivated nature, just like in the nineteenth century. Their distance from nature is well characterised by an attempt to establish a new sacred grove in Tallinn (the Sõjamäe sacred grove), and the introduction of indoor shrines (see, e.g., Hiis 1933: 88).

Studies of nature and nationalism have so far paid little attention to conservationists and forestry scientists, who also contributed to the story of Esthonus silvanus in the 1920s and 1930s. The history of Estonian forestry, discussed at the first Forestry Science Gathering in January 1923, appeared in accordance both with the national narrative and the concept of ethnic nature. Especially striking is the anti-German attitude, the representatives of which were blamed for forcing Estonians to deviate from their natural harmony with nature:

That the peasants gave no mercy to the forests was elementary: their only option was to sell products they got from the forests to provide for what little they could get done, as all of their time and labour belonged to the landlords. It is more than understandable that constant forced labour, centuries of weeding the forest and burning underwood did not engender a sense of compassion and love for the forest. (Daniel 1924: 18)

The eighth Estonian Forestry Science Gathering, in 1931, is interesting as folklorist Matthias Johann Eisen was invited to provide "an overview of how the forest is reflected in the soul of our nation" (Daniel 1931: 11). In his speech, Eisen declared that "the forest was sacred to ancient Estonians; some forests more, others less", "like the church in our day; hiis, a sacred grove, was a taboo back then" (Eisen 1931). His presentation was followed by a lively discussion in which Eisen stated that "in general, the forest is seldom mentioned in folk songs" and that this is "mainly a recent development". Despite this sceptical evaluation, forestry scientist Karl Verberg (Kaarel Veermets) claimed:

[T]here was a great respect for the forest in the ancient times. ... This was very beneficial to the preservation of the forest. ... Apparently, a new movement called Taara has appeared. ... Wouldn't it be reasonable for the foresters to spread the beliefs of this new old-fashioned religion among the people? Then people would have a new attitude towards the forest that allows better protection than required by law. I think foresters should become quite attentive followers of this ancient Taara faith. (Eisen 1931: 26) 
Whether this meeting can be considered a turning point or whether the shift occurred with the general rise of nationalism in the late 1920s and the 1930s is uncertain, but henceforth national romanticism was nearly ubiquitous in the speeches of forestry scientists and conservationists. Veneration of the forest was referred to as a fairly recent, although still past, phenomenon (e.g. Mathiesen 1937: 12-13), often intertwined with anti-German as well as anti-Christian stances (e.g. Viator 1936: 38), although in a slightly milder form than at the beginning of the $1920 \mathrm{~s}$ :

The Germans brought Christianity, which banished the old gods from the temples, but they still couldn't silence the sigh of our oaken forests. The forests became a refuge and a symbol of freedom. People complained to the spirits about the loss of their freedom and summoned up courage for battles whilst gathering secretly in sacred forests. (Sikk 1932: 393)

A more systematic creation of the Estonian national narrative began in the 1930s and was influenced by the nationalism then gaining relevance in Europe, but also by the rise of nationalist movements in Estonia, such as the Vaps Movement, the Estonian Nationalist Club, and the Taara faith movement. Now, the signs of relating nationality to religion and nature occurred clearly, as in the use of traditional sacred sites for national events. For example, the commemoration of the Saint George's Night Uprising (1343-1345) was celebrated in a "sublime mood" on the Tõrma sacred hill (Virumaa Teataja 1929) and similar celebrations took place all over Estonia in the 1930s. These events manifested the Esthonus bellator motif, binding ancient and modern history with national feelings.

Even some scholars contributed to the national myth, most active of them being Oskar Loorits (1932, 1939). His central motif was opposition to IndoEuropean, especially German, identity; therefore Loorits described Estonians (as well as other Finno-Ugric peoples) through the following antagonisms: Finno-Ugric inactivity and pacifism in opposition to Indo-European conquest and expansion; modesty and conservatism to the development of culture and technology; closeness to nature to Indo-European urban culture, etc. His narrative did not receive much attention during the $1930 \mathrm{~s}$, becoming influential to the national narrative only in the late 1980s and 1990s (Selart 2014: $155 \mathrm{ff}$.).

Defining Estonians as Finno-Ugric people had become a norm in the academic world by the early twentieth century. In 1927 the Fenno-Ugria organisation was founded with government support to develop relations with other FinnoUgric peoples. Madis Arukask (2018: 108) states that the subject of Finno-Ugric affairs "had a remarkable effect on society, especially the elites". However, its impact on national identity at that time seems to be weak, as in culture and 
politics Nordic countries were idealised, and "the Nordic beauty of our homeland" (Haavaniit 1940: 63) was emphasised.

One of the most important innovations in the creation of the national narrative in this era was the introduction of a new type of source - folklore. The first generation of folklore collectors had collected and published folklore but had not yet arranged it into a uniform story. Therefore, an appropriate situation had formed to include folklore in the creation process of a national narrative. Oral tradition is more diverse and more open to multiple interpretations than historical sources, which had thus far been dominant, providing proofs for both master motifs, the heroic warrior, and the hard-working farmer. In folklore collections, however, nature holds a notable place, allowing Loorits to compile a special volume of forest- and hunting-related folklore (Loorits 1941), dominated by stories of practical and utilitarian relations with nature. The few texts that praise the beauty of nature are written in a romantic style, posing the question of whether the whole concept of nature glorification derives from the romantic literature and school textbooks and has nothing to do with folklore. Here, Loorits' ideological position becomes very clear as he systematically describes the nature cognition of Estonians as a positive and equal relationship, ignoring the utilitarian attitude and potentially dangerous features of nature that dominate in the nineteenth-century folklore: "Perhaps the most charming characteristic of the Finno-kind peoples' religion is the great cognition of nature, reaching up to the devoted and humble veneration" (Loorits 1932: 66).

A practical aspect that influenced Estonians' relationship with nature was the systematic improvement of nature tourism in the $1930 \mathrm{~s}$, enforced by the romantic idea of the urban environment as an unnatural habitat. By the nineteenth century, parks had developed in towns (e.g. Toomemägi Park in Tartu and Kadriorg in Tallinn) "where one can forget mundane problems and enjoy nature, developing one's sense of beauty" (Suur 1938: 40) and "even be able to lie on the grass" (Lint 1938: 110). Now, with the development of motorised transportation, the focus drifts to 'recreational forests' around towns, especially promoted for the working class. More distant 'forest resorts' also became popular; for example, Taevaskoda, a scenic combination of pine forests and sandstone cliffs, which was little known until the railway was built in 1931. Since then it has become a favourite place to spend short holidays and weekends, considered today a natural sacred site.

The 1930s saw the beginning of the culture of active holidays - spending time in nature for recreational purposes. Part of the goal was to familiarise Estonians with the forest, as spending time in nature for non-utilitarian reasons was still foreign in the early years of the republic: 
A few decades ago, a simple park with a few flower patches, a few alleys and walkways in a geometric style, where groups could come for walks, was enough for the average citizen. Someone who tried to get closer to nature was considered a spoiled artist and a dreamer. (Seidra 1938: 80)

For that purpose, the Institute of Nature Preservation and Tourism was established in 1938, organising forestry days, discussing forest-related topics at schools, and spreading popular works on forestry, hiking, and nature tourism (e.g. Kompus 1939). This was mainly directed towards city dwellers, who had access to media and transport and were more open to modern changes than people living in the countryside (Jürgenson 2005: 38). These changes fell in line with the popularisation of local tourism due to the growing tensions in the European political landscape.

Thus, during the interwar period, a set of ideas was established which later enabled the development of the Esthonus silvanus motif, most importantly the concept of ethnic nature. National identity and nature did not yet form a uniform narrative, but as a step towards it, Estonians' relationship with local nature was projected into the long-gone golden ages and then mirrored into recent history. Still, it seems that these views did not gain broader societal resonance at that time.

\section{THE SOVIET ERA: OLD MOTIFS, NEW SHAPES}

According to Marek Tamm (2008), the main outlines of the Estonian national narrative had taken shape by the end of the independence era and the Soviet period had surprisingly small influence on the patterns of national historical memory. The fight for Estonian cultural perseverance - now presented in the form of Marxist class struggle - indeed remained the backbone of the national narrative, although some new motifs did emerge, among them the motif of the intimate Estonian relationship with nature, shaped by a number of contrasting factors.

The first factor was the earlier concept of Estonians as a Finno-Ugric nation, which became popular in the 1960s and 1970s, as the Soviet ideology supported the idea of finding one's cultural roots from within Russian territory. Thus, for Estonian scholars, ethnographic expeditions offered the possibility to study something both exotic and their own. This also fell in line with an important slogan of Soviet cultural policy: "National in form, socialist in content", meaning that different national concepts and practices should be filled with socialist ideology (see also Annus 2019). 
Despite the ideological desires, Finno-Ugrism is one of the examples of subtle anti-colonial developments in national cultures. Kuutma (2005) describes the Finno-Ugric cultural marker as an "imaginary Finno-Ugric wall", which Estonians used as intellectual resistance against Soviet ideology and cultural hegemony. In Soviet ideology, the past had negative connotations ("vestiges"), while the future held the goal of a utopian state. Finno-Ugrism emphasised exactly the opposite: the main context of the "Finno-Ugric wall" was the search for authenticity from one's own past and locality. The connection with ancient authenticity was created through the Finno-Ugric kindred peoples, mirrored to both ancient and contemporary Estonians. Through this (self-reflexive) concept of the noble savage, Estonians were compared to Native Americans, emphasising harmonious co-existence with nature.

Associating Estonians with Finno-Ugrians provided a framework that combined both cultural and ecological references by introducing a new connection, common belonging to the forest belt: "Sacred groves and sacred trees became the most important objects of veneration, probably because we are a traditional forest belt nation" (Relve 1982a: 313), also emphasising a common naturefriendly worldview: "[P]erhaps we should favour more the ancient animistic religion that provided support for a more controlled behaviour [towards nature]" (Relve 1982a: 312). Valuing the culture of kindred Finno-Ugric peoples had a certain impact on art, literature, music, and other domains of creative arts, which further supported this new traditionalism.

Many of the creative intelligentsia were associated with the Estonian Society for Nature Conservation (ESNC), founded in 1966. In the activities of the ESNC, the goals of conservationism and culture preservation were entangled with nationalist ideas - another example of the subtle "lived anti-colonialism" of Soviet-era everyday life. As a result, articles by folklorists about the forest and folklore were published in the popular journal Eesti Loodus (Estonian Nature), which provides a perfect basis for studying the development of the idea of the connection between Estonians and nature. These associations do not appear in the 1960s but are clearly visible from the 1970s onwards. Initially they emerge as projected onto the past, often through kindred nations: "A close relationship with the forest was the cause of deep feelings towards nature and a tender attitude towards this element of everyday life" (Viires 1970). Soon, the connection was presented as of contemporaneous relevance: "Nevertheless, we are the descendants of the traditional inhabitants of the forest" (Viires 1975: 7).

Another strand that influenced the ideas about Estonians and nature was the nature writing genre. This tradition had begun with travelogues in the interwar era and continued in the form of animal stories and nature descriptions after the war (e.g. Johannes Piiper, Richard Roht, Eerik Kumari). The 1970s 
saw the emergence of a new generation of 'nature mediators': Fred Jüssi, Rein Maran and others, whose approach was very personal, tender, and intellectual, as philosophical topics dominated over aesthetic or social-economic aspects (Tüür \& Maran 2005: 264). The importance of nature writing and nature mediators became apparent already in the 1980s: "It seems that a relationship with nature through nature and its mediators prevails over the direct relationship. These mediators prepare opinions and attitudes that people who go on vacation subconsciously take into account" (Relve 1982b: 231).

While the 'Finno-Ugric wall' and nature writing offered an intellectual background to the formation of the concept of forest nation, other aspects, like nature tourism, were connected with the actual forest practices of the increasingly urbanised descendants of the 'primeval forest people' - by the 1970s almost two thirds of the population was urban (Beltadze 2012: 12). Spokespersons of conservationists and healthcare saw the separation from nature as a negative phenomenon: "observations prove that those holiday-makers who just go walking in the forests, are very few in numbers" (Palm 1983: 26) while "living in the cities deepens the lack of interest towards the nature as the urban milieu itself hardens peoples' spiritual life and emotions" (Kumari 1973: 158).

The 1970s saw the rapid development of nature tourism, propellered by a set of different changes: the development of "recreational forests" around towns, with a suitable infrastructure such as fireplaces and hiking trails (Kumari 1973: 347), and the creation of conservation areas and national parks such as Lahemaa National Park in 1971, the first one in the Soviet Union. Two additional changes contributed to the increase in nature tourism: the five-day work week since 1966, and the decision to increase the sale of private cars in 1971 (Margus 1983: 101). Thus, paradoxically, the closeness to nature is inevitably connected to ecologically harmful transportation - according to contemporary statistics, car owners spent time in nature three times more than those who did not own a personal vehicle (Lausmaa 1983: 30). Nature tourism was also supported by the popularisation of gathering mushrooms and berries.

These changes resulted in a tourist boom that created "a so-called one-hour tourist, who agrees to leave the bus or car for no longer than one hour and no farther than 500 meters" (Ranniku 1976), while "solo hikers who have escaped the urban milieu were replaced by hordes roaming around the bogs to gather berries in the autumn, which has created serious problems [for the environment]" (Aruja 1983: 66).

In conclusion, during the Soviet period the goals of environmentalism became closely combined with preserving Estonian culture, giving rise to the motif of Estonians' intimate relationship with nature, thus creating fertile ground for the establishment of the concept of 'Estonians as a forest nation'. 


\section{THE PERIOD OF TRANSITION TO INDEPENDENCE AND THE ERA OF INDEPENDENT ESTONIA}

In the 1980s, large-scale Soviet industry and its accompanying immigration concurrently threatened both the environment and Estonian national identity. This resulted in the close entanglement of environmental and national ideas (Tüür \& Maran 2005), culminating in the so-called Phosphorite War in 1987. As a result of this tension and together with earlier developments, in the last years of the Soviet system the concept of Estonians as a forest nation emerged.

The expression "forest nation" was actually in use beforehand, signifying the inhabitants of the forest - that is, birds and animals (Fig. 1). One of the first occurrences of this expression for an ethnic category was in December 1988, when archaeologist Heiki Valk spoke in the Estonian Public Broadcasting programme of Estonians as a forest nation (Mõttekiir 1988). Although this is the earliest use of the expression in such a meaning known to the authors, very likely the idea circulated already before amidst a smaller group of Estonian intellectuals but had not been used in print. This concept fell on fertile ground, as demonstrated by the rapid rise in usage of this expression in the following decades (see Table 1), skyrocketing during the debates over forest management in the second decade of the twenty-first century. Today, the expression is used mainly as an ethnic category.

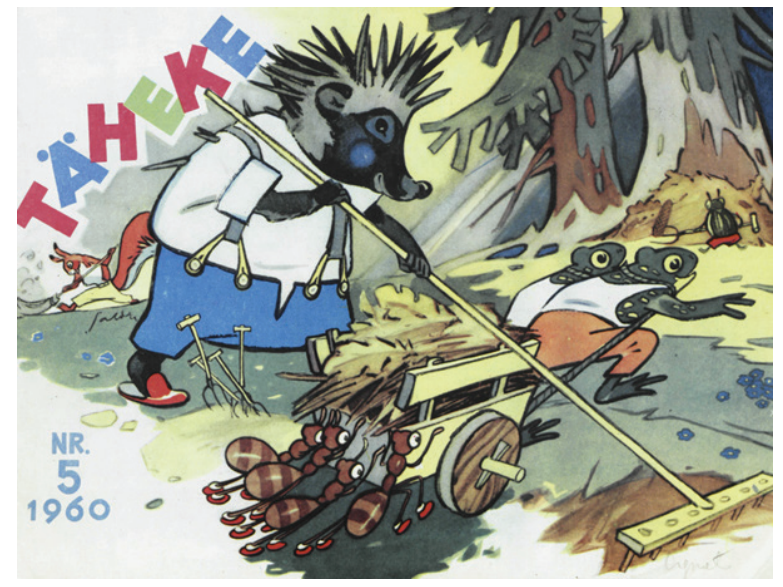

Figure 1. A. Saldre's drawing titled "Forest Nation at Work". Cover of the children's journal Täheke (Starlet), May 1960. 
Table 1. The occurrence of search-word "metsarahva" (forest nation) in Estonian periodicals. ${ }^{1}$ The table does not include the occurrences of the same idea with different wording, and one must take into account that older texts are less frequently digitised.

\begin{tabular}{|l|r|}
\hline Decade & Frequency \\
\hline $1890-1899$ & 1 \\
\hline $1910-1919$ & 2 \\
\hline $1920-1929$ & 3 \\
\hline $1930-1939$ & 10 \\
\hline $1940-1949$ & 5 \\
\hline $1950-1959$ & 5 \\
\hline $1960-1969$ & 30 \\
\hline $1970-1979$ & 14 \\
\hline $1980-1989$ & 8 \\
\hline $1990-1999$ & 39 \\
\hline $2000-2009$ & 241 \\
\hline $2010-2019$ & 2035 \\
\hline 2020 & 211 \\
\hline
\end{tabular}

For Estonian identity, the collapse of the Soviet Union changed perspectives and reference points. Concerning nature, perspective moved from forested Siberia to (Western) Europe, which, compared to Estonia, seemed like a cultivated land without forest: "A good relationship with nature helps to improve our international image, which helps to draw nature-loving visitors to Estonia” (Soots 1991).

The aspect of international tourism brought a new force into narrative creation - the publicity industry, with its unruly fantasy and prospects surpassing the total of any earlier Estonian identity creation. Previously, the rhetoric about Estonians' relationship with nature had been directed towards a domestic audience, but since the 1990s Estonian nature has been increasingly marketed internationally. As a result, a new motif emerges, which speaks of untouched Estonian nature and describes Estonia as a new green Eden, presenting it both in the context of nature tourism and (existential) health (see Fig. 2). Green Eden rhetoric is then associated with authenticity that rises from the special relationship between Estonians and nature, which, in turn, is used in the 'ecoisation' of local products (see Fig. 3).

Aside from the marketing industry, the most influential vehicle for the forest nation archetype is the identity literature - publications that deal with the aspects of Estonianness, often in popular scientific form. This literature has appeared since the $1990 \mathrm{~s}$, when the authors started to be published who were banned during the Soviet period, most notably by Oskar Loorits and Uku Masing. 


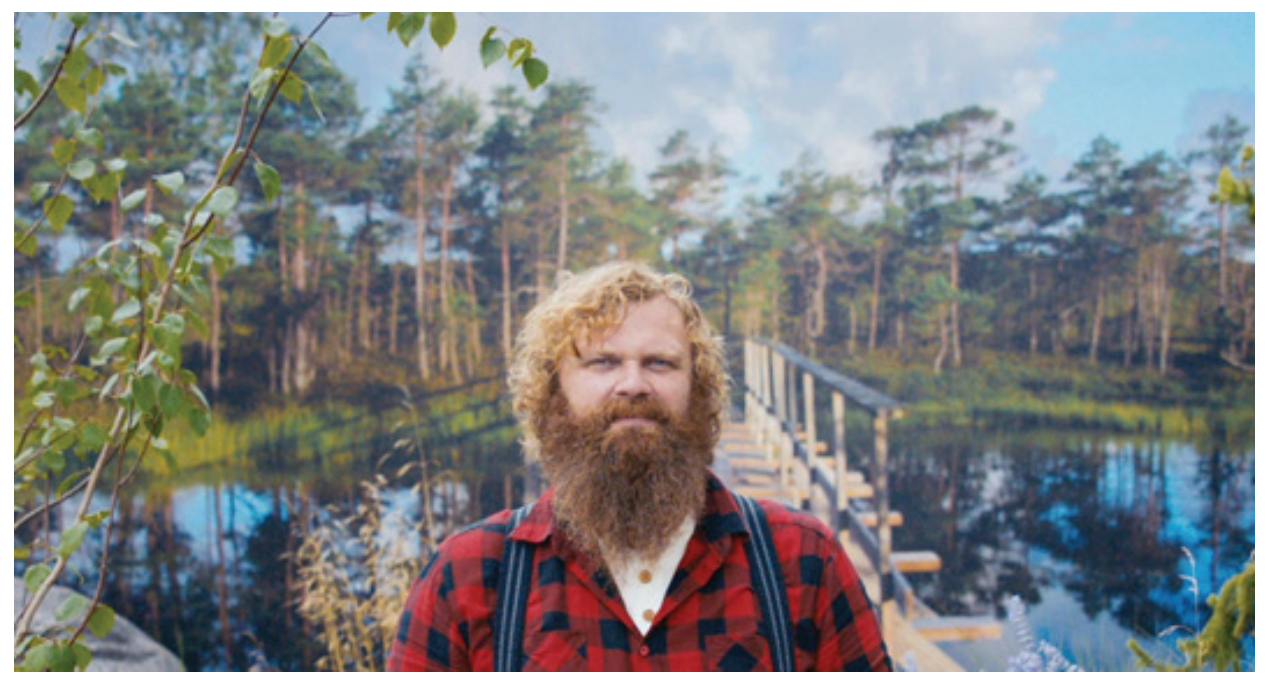

Figure 2. Estonian Stress Buster: Let Estonia's pure nature relieve your stress. We have come to accept stress as a normal part of our lives. But it does not have to be that way. The Estonian Stress Buster has the antidote. Source: https: / / defol.io / kuldmuna /2018the-estonian-stress-buster, last accessed on 4 January 2020.

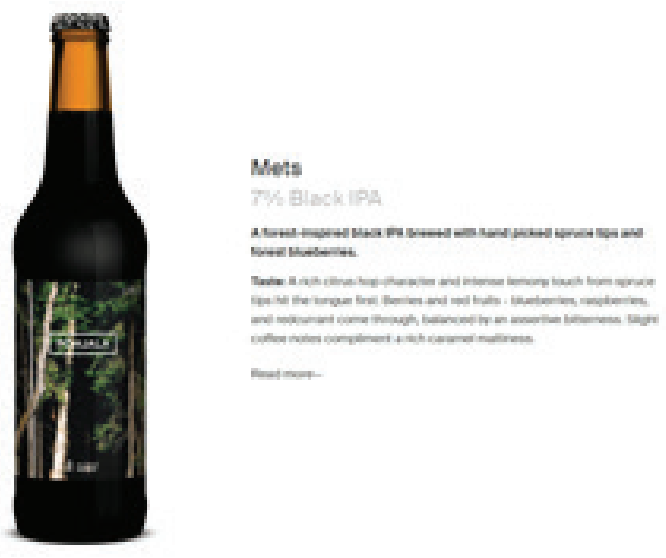

Figure 3. Description of the product from Põhjala Brewery: The forest has a deep influence on Estonian culture and cuisine. This heritage is embodied in our Forest Series. In these editions, we twist rare botanicals, forest ingredients, and Estonian folk-medicine with ancient methods into absolutely extraordinary beers. Source: https: / / pohjalabeer. com / forest-series, last accessed on 16 December 2020. 
Their ideas were used as intellectual proof of Estonians as forest people, supported by new identity literature, originating from contemporary paganism as well as academic circles. During and after this wave the Estonian relationship with nature has become a favourite topic of many authors, of whom Valdur Mikita has become the most influential identity writer. The core of Mikita's narrative is about the Eastern European forest zone and specifically Estonian nature, its specialty, and the human relationship with nature, entangled with the unfolding ecological catastrophe (Kaljundi 2018). As a result, Mikita highlights Estonians to the rest of the world, especially to Western Europeans, who have lost their nature. This storyline is attractive and easily consumable, as indicated by the sales figures of his books as well as the use of his ideas by people who have never read his books - a clear indicator of an idea going 'national'.

The forest nation motif is actual due to the continuous debate over Estonian forest management policy that started already in the 1990s. Interestingly, one of the arguments to support the idea of the forest nation and to restrict extensive logging has been a reference to Estonia as a historically forested country. Compared to the interwar period, when Estonia as a forested country was referred to in the past tense as only about 20 percent of Estonia was forested, the percentage of forested areas increased to more than 50 percent by 2016 (Servinski \& Kivilaid \& Tischler 2018: 22-23). The growth was a result of the Soviet period abandonment of cultivated land and grasslands due to collective farming and urbanisation; nature conservancy and the creation of national parks, but also due to restricted access to border zones and numerous Soviet Army military bases. This aspect contains a significant dissonance as the Soviet period is considered negative, yet it created one of the most important and positive identity markers for contemporary Estonians.

Thus, in the debate over forest management, two opposites collide: on the one hand, the memory of the forested Soviet Estonia, on the other hand, a pragmatic attitude towards the forest as a renewable natural resource that ripens regularly. This debate culminated in 2015 and subsequent years, when the protests and demonstrations (for example, the so-called white willow affair in 2017 (Annist 2020) and the 'Emajõe chain' protest against building a cellulose factory in 2018 (Kõiv 2020)) could even be compared to the Phosphorite War in the 1980s, and impelled the foundation of several civil society organisations (e.g. Eesti Metsa Abiks (Estonian Forest Aid) in 2016). During this debate, Estonians' intimate relationship with nature acquired the value of a national treasure, which, along with the conservancy arguments has managed to influence political decisions, such as the abandonment of the cellulose factory beside the Emajõgi River. 
Another aspect influencing the entrenchment of the Esthonus silvanus motif has been the development of nature tourism. The Estonian State Forest Management Centre (SFMC) has created an extensive network of hiking trails, cabins for overnighting, etc., which offer a quick and safe relationship with nature along with carefully planned environments with lakes, rivers, bogs, and beautiful sightseeing spots. But nature tourism depends on transport. In 1990 there were 240,900 registered cars in Estonia, which doubled in ten years to 463,883 , reaching 746,464 in 2018 (Statistics Estonia 2020). Considering the Estonian population of 1.3 million, this impressive number in combination with SFMC's advertisement campaigns, which often use national motifs, is well reflected in the SFMC statistics: in 2014 recreational and conservancy areas were visited $1,900,000$ times, the number reaching 2,700,000 in 2018 (SFMC 2018: 44), with more than 75 percent of the visitors being domestic tourists (Ehrlich 2013: 26).

Although Estonia is considered one of the most secular countries in Europe (Pickel \& Pollack \& Müller 2012), religion plays a significant role in the development of the concept of Esthonus silvanus. During the religious boom at the end of the 1980s, a contemporary pagan movement Maausk (Earth Belief), supported originally by a small circle of intellectuals, became public. In the late 1980s and in the 1990s, Maausk agenda was mainly religious, including the restoration of sacred groves and the propagation of Maausk as a native and traditional religion (Västrik 2015). The 2000s, however, marked the period of Maausk public campaign to protect sacred groves, threatened by various economic activities. As a result, a certain spiritual aspect was included not only to sacred sites but also to nature in general, which was not present during the Phosphorite War 15-20 years earlier.

This 'holy war' significantly increased the visibility of Maausk, which started to present itself not so much as a religious organisation, but rather as a movement devoted to maintaining and protecting national cultural heritage. This made their agenda acceptable for people who did not identify as Maausk, and became a foundation of their wider popularity - while only 4 percent of ethnic Estonians consider themselves followers of Maausk, more than 60 percent agreed that Maausk is Estonia's true religion (RTE 2014). Thus, Maausk is not a majority religion, but enjoys high reputation due to successful identity politics and rhetoric on conservation, so that Maausk is perceived more as a (secular) culture rather than a religious movement (Jonuks 2017; Remmel 2019; see also Kõiva et al. 2020).

Today, the entanglement of forest/nature, national identity and religion has three main storylines. Firstly, the image of Estonians as religiously tepid nation. This concept, formed in the early twentieth century and cultivated during the period of Soviet atheist propaganda, saw a recent revival due to sociological 
surveys, which pointed out the unimportance of Christianity, creating a motif of Estonians as "the most atheist nation in the world" (Remmel 2016). Concurrently, sociological surveys also revealed the popularity of non-institutional beliefs, such as animism, which is used to support the Esthonus silvanus concept. ${ }^{2}$ The result is a curious operation of identity mathematics: Estonians as atheists + Estonians as a forest nation = the forest is Estonia's church.

The second storyline derives from a health-related functional aspect: both nature and religion (churches) are considered consolations, providing security or silence for self-reflection. Therefore, both Estonian nature and Estonians' intimate relationship with it becomes a peculiar 'existential resource'. As a result, the earlier negative expressions are sometimes used in a positive sense. For instance, the expression mine metsa! ('get lost!', literally: go to the forest!) was explained by an interviewee, "Well, it actually means go to the forest and get yourself in order, get your thoughts right..." (Luule, F: 53). ${ }^{3}$ The third aspect is about aesthetics, as both churches and forest trails are dim and silent, and the trees bending together high above the ground resemble vaulted church ceilings. Yet, 'religious' in this context often seems to be used only in the metaphorical sense, as a shorthand for existential importance. In that respect, 'religion' has become less religious.

\section{CONCLUSION}

National narratives are not the stable homogenous stories that they claim to be. Instead, national narratives include different stories from which suitable elements are chosen that actualise in specific situations. These stories operate in constant interaction with the societies that produce them and which they concurrently more or less influence.

Associating ethnic cultures with local nature reaches back to the eighteenthcentury Enlightenment and the concept of the noble savage. In the Estonian case, the forest did not have a significant position in identity formation. Instead, in the nineteenth-century folk culture, the forest had neutral or even negative connotations. One can find positive treatments of the forests only in the (neo-) romantic nature descriptions of the beginning of the twentieth century, which also carried a certain anti-urbanist agenda. This agenda became prominent during the interwar period, especially due to the growing association of nature and health in the 1930s. Along with the development of recreational forests near the cities, the promotion of an active relationship with nature emerged as an important factor. This tendency was also supported by the general rise in the living standards and a broader appearance of the middle class. In such 
a context nature was not merely a resource for the living but provided aesthetic and emotional qualities - enjoyed by the nobility already in the eighteenth and nineteenth centuries, yet now being available for a broader population.

However, the most important change that followed the creation of the independent Republic of Estonia and the agrarian reform was the emergence of the concept of ethnic nature - the treatment of nature within certain geographical boundaries and through the lens of nationalism. This understanding supported the tendency to ascribe close connection to (ancient) Estonians and nature - the motif appearing already in the late nineteenth century, but becoming widely used in the 1930s by nature conservationists, who combined cultural elements with conservationism, finding arguments from the former for the latter. Since then, conservationist arguments have remained an important undercurrent in the Estonian national narrative, actualising at suitable moments in different forms, for instance in the 1960s and 1970s in association with the creation of national parks and the popularisation of nature's role in recreation. These decades were also a period of rapid development in transport that together with the development of hiking trails and tourism culture helped to facilitate a new form of quick and safe relationship with nature.

The 1960s also saw the re-emergence of Finno-Ugrism as an important cultural marker. The revitalisation of the 'noble savage' imagery to describe the culture of linguistically kindred nations soon had an effect on Estonians' self-perception. Mirroring the nature-friendly worldview of the kindred peoples, first to the ancient Estonians and then in the 1970s to contemporary Estonians, introduced an idea about belonging to a kin group of traditional forest-belt nations. Finno-Ugrism influenced different kinds of creative art, thus founding a new set of traditionalisms. At the same time a new generation of nature mediators emerged, their books carrying the idea of Estonians' intimate relationship with nature.

These developments paved the way to the next milestone. The 1980s could be regarded as another crucial decade after the emergence of the concept of ethnic nature in the 1920 s, as the precisely formulated concept of Esthonus silvanus was probably first worded in the 1980s, apparently initially within a narrower circle, but then publicly by the end of the decade. The emergence of Esthonus silvanus not earlier than the 1980s can also be explained by the fact that only by the later years of Soviet rule in Estonia was there so much forest as to leave an impression of a heavily forested country. Thus, the arguments about Estonians' intimate relationship with the forest did not seem a retrospective mirage but a tangible reality.

The Phosphorite War in the 1980s together with the concept of Esthonus silvanus allowed the earlier understanding of ethnic nature to develop into 
eco-nationalism - the idea that Estonian culture and nature are inherently entangled and, by protecting nature, Estonian culture is also preserved. This concept has remained very much alive in the context of the debates over logging policy after the collapse of the Soviet Union, as is the idea of Estonians' special relationship with nature. Thus, it seems that the emergence of Esthonus silvanus as part of the widespread 'national' narrative did not occur before the 1990s or even the 2000s. The idea was still spearheaded by the creative intelligentsia (e.g. Valdur Mikita), but began to be widely promoted by eco-communities, advertising, and tourism, and most influentially by contemporary paganism, with selected elements presented as authentic native heritage, appealing to the historicity of the concept.

Although we described the development of Esthonus silvanus as non-linear, a universal change has developed in the background. Emerging from a nineteenth-century Romanticism and anti-urbanist agenda, the forest, or nature in general, has changed from a mainly negative or neutral place to an exclusively positive resource over the last century. Due to this the Estonian national narrative is not the only one to include the motif of a close national relationship with nature - one can find "cognate motifs" from Germany, Finland, Sweden (Thurfjell 2020), and elsewhere. This semantic change, supported today by the climate change debate, has opened the way to new interpretations and has made the forest an attractive element not only for (national) identity creation, but also for (existential) health, religion, tourism, and many other fields (Hastrup \& Rubow 2014; Ohlsson 2020). Yet, during this process of 'ecoisation', the forest and nature often lose their initial content and become - just like science - only a signifier of high social capital for better marketing.

Thus, the story of Esthonus silvanus was formed at the crossroads of very different ideas and processes, affected by changes in the political order, forest practices, urbanisation, and various other factors. These ideas were selected through contemporary values, and legitimised through references to history, therefore they do "not represent a real relationship with nature, but an imagination of how things should be" (Valk 2005: 40).

\section{ACKNOWLEDGEMENTS}

The article was written with support from the Baltic Sea Foundation's grant "Relocation of transcendence: The sacred of the seculars around the Baltic Sea"; Estonian Research Council grants "Narrative and belief aspects of folklore studies" (IUT 22-5, EKM 8-2/20/3), and "Estonian environmentalism in the 20th century: Ideology, discourses, practices" (PRG 908), the Centre 
of Excellence in Estonian Studies (CEES, TK-145), and "Re-storied sites and routes as inclusive spaces and places: Shared imaginations and multi-layered heritage" (EMP340), funded by the EEA Financial Mechanism 2014-2021, Baltic Research Programme in Estonia.

\section{NOTES}

1 See dea.digar.ee, last accessed on 16 December 2020.

2 According to LFRL 2015, 63 percent of ethnic Estonians agreed that "plants have a soul". Yet, according to secondary cognitive testing, the agreement very likely means that plants are alive, therefore interpreting the data as animism is questionable.

${ }^{3}$ Interviews (unpublished) were conducted by Atko Remmel in 2017-2019 as a part of the project: "Relocation of Transcendence: The sacred of the seculars around the Baltic Sea", funded by the Baltic Sea Foundation.

\section{REFERENCES}

Aarelaid, Aili, \& Relve, Henrik 1980. Kõnelused loodusnägemisest. [A Conversation about Nature Perception.] Looming, No. 1, pp. 92-102.

Anderson, Benedict 2016 [1983]. Imagined Communities: Reflections on the Origin and Spread of Nationalism. Revised edition. London \& New York: Verso.

Annist, Aet 2020. Introduction: Performance, Power, Exclusion, and Expansion in Anthropological Accounts of Protests. Conflict and Society, Vol. 6, No. 1, pp. 183200. http://dx.doi.org/10.3167/arcs.2020.060111.

Annus, Epp 2019. Sotskolonialism Eesti NSV-s: võim, kultuur, argielu. [Social Colonialism in the Estonian SSR: Power, Culture, Everyday Life.] Tartu: Tartu Ülikooli Kirjastus.

Annus, Epp 2000. National Mythology: Past and Present. Interlitteraria, No. 5, pp. 115130. Available at https://dspace.ut.ee/handle/10062/54891, last accessed on 17 December 2020.

Aruja, M. 1983. Maastikukaitse ja puhkus. [Forest Protection and Vacation.] In: E. Varep (ed.) Looduskaitse ja puhkus. Tallinn: Valgus, pp. 65-74.

Arukask, Madis 2018. Soomeugrilusest Eesti rahvuspildis - kas jagatud emotsioon või hägune küsitavus? [Finno-Ugric Kinship in the Estonian National Image: A Shared Emotion or a Fuzzy Question?] Keel ja Kirjandus, No. 1-2, pp. 104-117. Available at https://dea.digar.ee/cgi-bin/dea?a=d\&d=AKkeeljakirjandus201801.2.24, last accessed on 17 December 2020.

Auerbach, Yehudith 2009. The Reconciliation Pyramid: A Narrative-Based Framework for Analyzing Identity Conflicts. Political Psychology, Vol. 30, No. 2, pp. 291-318. http://dx.doi.org/10.1111/j.1467-9221.2008.00692.x. 
Baer, Carl Ernst von 2013 [1814]. Eestlaste endeemilistest haigustest. [Estonians' Endemic Diseases.] Transl. by Ülo Torpats. Tallinn: Hea Lugu.

Beltadze, Diana 2012. Eesti rahvaarv, rahvastiku koosseis ja paiknemine 2011. aasta rahvaloenduse tulemuste põhjal. [The Size, Structure, and Distribution of the Population of Estonia Based on the 2011 Census.] Eesti Statistika Kvartalikiri, No. 4, pp. 6-20. Available at https://www.digar.ee/arhiiv/et/raamatud/63134, last accessed on 17 December 2020.

Coakley, John 2004. Mobilizing the Past: Nationalist Images of History. Nationalism and Ethnic Politics, Vol. 10, No. 4, pp. 531-560. https://doi. org/10.1080/13537110490900340.

Cosgrove, Denis 2003. Landscape: Ecology and Semiosis. In: Hannes Palang \& Gary Fry (eds.) Landscape Interfaces: Cultural Heritage in Changing Landscapes. Dordrecht \& Boston \& London: Kluwer Academic Publishers, pp. 15-20.

Daniel, Oskar 1924. Meie metsanduse ajalugu. [The History of Our Forestry.] In: I Metsateadlaste päev, Tartus, 5. ja 6. jaanuar 1923. a. Tartu: Akadeemilise Metsa Selts, pp. 9-27.

Daniel, Oskar 1929. Mets ja metsandus Eestis. [Forest and Forestry in Estonia.] Tallinn: Riigimetsade Valitsus.

Daniel, Oskar 1931. Päeva avamine. [Introduction.] In: Karl Verberg (ed.) Eesti metsanduse aastaraamat. Tartu: Akadeemiline Metsaselts, pp. 7-13.

Dawson, Jane I. 1996. Eco-Nationalism: Anti-Nuclear Activism and National Identity in Russia, Lithuania, and Ukraine. Durham \& London: Duke University Press.

Dronin, N. M. \& Francis, J. M. 2018. Econationalism in Soviet Literature. The Soviet and Post-Soviet Review, Vol. 45, No. 1, pp. 51-72. https://doi.org/10.1163/1876332420171260.

Ehrlich, Üllas 2013. Eesti loodusturism kui majandusharu. [Nature Tourism in Estonia as an Industry.] Tallinn: n.p. Available at http://ec.europa.eu/environment/ nature/legislation/fitness_check/evidence_gathering/docs/Member\%20State\%20 Stakeholders/Nature\%20Protection\%20Authorities/EE/MS\%20-\%20EE\%20-\%20 NPA\%20-\%20Loodusturism_Ehrlich.pdf, last accessed on 17 December 2020.

Eilart, Jaan 1961. "Kalevipoeg" ja looduskaitse. ["Kalevipoeg" and Conservancy.] Eesti Loodus, No. 4, pp. 216-223. Available at https://www.digar.ee/arhiiv/et/ perioodika/91905, last accessed on 17 December 2020.

Eisen, Matthias Johann 1931. Mets vanarahva arvamises. [The Forest in Folklore.] In: Karl Verberg (ed.) Eesti metsanduse aastaraamat. Tartu: Akadeemiline Metsaselts, pp. 14-26.

FES 2011 = Eesti Fraseologismide Elektrooniline Alussõnastik. [Electronic Dictionary of Estonian Phraseologisms.] Compiled by Asta Õim \& Katre Õim. Available at http://www.folklore.ee/justkui/sonastik/index.php?otsing=mets\&paring=Otsi, last accessed on 16 December 2020.

Friebe, Wilhelm, Christian 1794. Handbuch der Geschichte Lief- Ehst- und Kurlands zum Gebrauch für Jedermann von Wilhelm Christian Friebe, Mitglied der Freyen Ökonomischen Gesellschaft in St. Petersburg. Riga: Christian Friedrich Hartknoch. 
Germann, Gottfried Albrecht 2018 [1803]. Reis mööda Eestimaad, eeskätt botaanilise sisuga. [Trip Around Estonia, Mostly Botanical.] Transl. by Malle Salupere. Akadeemia, No. 6 (1805), pp. 1013-1040.

Haavaniit, A. 1940. Loodusilust sõnas ja pildis. [Beauty of Nature in Words and Pictures.] Loodushoid ja turism, No. 1, pp. 62-63.

Hastrup, Kirsten \& Rubow, Cecilie (eds.) 2014. Living with Environmental Change. Waterworlds. London: Routledge.

Hein, Ants 2007. Aed ja aeg: Piirjooni Eesti aiakunsti vanemast ajaloost. [Garden and Time: Contours of the History of Estonian Horticulture.] In: Elo Lutsepp (ed.) Eesti pargid 1. Tallinn: Keskkonnaministeerium \& Muinsuskaitseamet \& Varrak, pp. $15-87$.

Helm, P. 1924. Tammikute seisukord kodumaal enne ja nüüd. [Oak-Forests in Estonia Before and Now.] In: I Metsateadlaste päev, Tartus, 5. ja 6. jaanuar 1923. a. Tartu: Akadeemilise Metsa Selts, pp. 56-74.

Heraklides, A. 1908. Eesti usk. [Estonian Religion.] Tallinn: Mõte.

Herder, Johann Gottfried 1773. Auszug aus einem Briefwechsel über Ossian und die Lieder alter Völker. Available at http://www.uni-due.de/lyriktheorie/texte/1773_ herder.html, last accessed on 17 December 2020.

Hiis 1930a = Loomulikul teel. [In a Natural Way.] Hiis: Taarausuline ajakiri, No. 1, pp. 4-14. Available at https://www.digar.ee/viewer/et/nlib-digar:403239/344766/ page/2, last accessed on 22 December 2020.

Hiis $1930 \mathrm{~b}=$ Kuidas pühitseme oma jõule? [How Do We Celebrate Christmas?] Hiis: Taarausuline ajakiri, No. 2, pp. 26-29. Available at https://www.digar.ee/viewer/ et/nlib-digar:403240/344767/page/3, last accessed on 22 December 2020.

Hiis 1933 = Ülevaade Hiie tegevusest E. V. 15. aastal. [An Overview of the Activities of Hiis on the 15th Year of the Estonian Republic.] Hiis: Taarausuline ajakiri, No. 4, pp. 87-91. Available at https://www.digar.ee/viewer/et/nlib-digar:403242/344765/ page/17, last accessed on 22 December 2020.

Hobsbawm, Eric \& Ranger, Terence (eds.) 1992 [1983]. The Invention of Tradition. Cambridge: Cambridge University Press.

Hroch, Miroslav 1985. Social Preconditions of National Revival in Europe: A Comparative Analysis of the Social Composition of Patriotic Groups among the Smaller European Nations. Transl. by Ben Fowkes. Cambridge: Cambridge University Press.

Hupel, August Wilhelm 1777. Topographische Nachrichten von Lief- und Ehstland. Band II. Riga: Johann Friedrich Hartknoch. Available at https://dspace.ut.ee/ handle/10062/1888, last accessed on 17 December 2020.

Imort, Michael 2005. A Sylvan People: Wilhelmine Forestry and the Forest as a Symbol of Germandom. In: Thomas Lekan \& Thomas Zeller (eds.) Germany's Nature: Cultural Landscapes and Environmental History. New Brunswick, N.J.: Rutgers University Press, pp. 58-80.

Jakobson, Carl Robert 1991 [1868]. Kolm isamaa kõnet. [Three Fatherland Speeches.] Tallinn: Eesti Raamat.

Jansen, Ea 2004. Vaateid eesti rahvusluse sünniaegadesse. [Insight into the Beginning of Estonian Nationalism.] Tartu: Ilmamaa. 
Jonuks, Tõnno 2009. Eesti muinasusund. [Prehistoric Religions in Estonia.] Tartu: Tartu Ülikooli Kirjastus.

Jonuks, Tõnno 2017. New Trends in the Study of Religion in Estonia: Contemplations in the Grey Zone between Religion and Science. In: Ekaterina Anastasova \& Mare Kõiva (eds.) Balkan and Balticum: Current Studies in the Postsocialist Space. Sator, Vol. 18, pp. 161-82. https://doi.org/10.7592/Sator.2017.18.08.

Jürgenson, Aivar 2005. Seened kultuuriloos. [Mushrooms in Cultural History.] Tallinn: Argo.

Kaljundi, Linda 2018. Eestlased kui soomeugrilased. [Estonians as Finno-Ugrians.] Vikerkaar, No. 1-2. Available at http://www.vikerkaar.ee/archives/22491, last accessed on 17 December 2020.

Kents, Jakob 1947. Eesti "kõrve"-nimelised kohad - ürgse maastiku ja asustusloo ilmendajad. ['Kõrve'-places in Estonia.] Tartu: Teaduslik Kirjandus. Available at https://dspace.ut.ee/handle/10062/17412, last accessed on 18 December 2020.

Kõiv, Henri 2020. Tehas, mis lõhestas ühiskonna. [The Plant That Divided the Society.] Vikerkaar, No. 3, pp. 31-112. Available at https://dea.digar.ee/cgi-bin/dea?a=d\& d=AKvikerkaar202003.2.13, last accessed on 18 December 2020.

Kõiva, Mare \& Jonuks, Tõnno \& Kalda, Mare \& Kuperjanov, Andres \& Hiiemäe, Reet 2020. Marking of Sacred Places. Trames, Vol. 24 (74/69), No. 2, pp. 129-144. https//doi.org/10.3176/tr.2020.2.01.

Kompus, Hanno 1939. Maaliline Eesti: pilte Eesti ilusaist ehitustest, maastikest ja muist vaatamisväärsustest. [Scenic Estonia.] Elav Teadus. Eesti Kirjanduse Seltsi populaarteaduslik seeria 96. Tartu: Eesti Kirjanduse Selts.

Kreutzwald, Friedrich Reinhold 1862. Kalewi poeg: üks ennemuistene Eesti jut: kaheskümnes laulus. [The Son of Kalev: An Old Story in Twenty Songs.] Kuopio: P. Aschan ja Co. Available at https://www.digar.ee/arhiiv/et/raamatud/46478, last accessed on 18 December 2020.

Kruus, Hans 1940. Eesti rahva ajaloolise kutsumuse ideest. [On the Historical Vocation of Estonians.] In: Eesti Üliõpilaste Seltsi Album XI. Tartu: Eesti Üliõpilaste Seltsi Kirjastus, pp. 7-23.

Kumari, Eerik 1973. Looduskaitse. [Conservancy.] Tallinn: Valgus.

Kuutma, Kristin 2005. Vernacular Religions and the Invention of Identities behind the Finno-Ugric Wall. Temenos, Vol. 41, No. 1, pp. 51-76. https://doi.org/10.33356/ temenos.4802.

Laanes, Eneken 2012. Vaba mees Bornhöhe “Tasujas”. Kultuurimälu, rändavad vormid ja rahvuse rajajooned. Keel ja Kirjandus, No. 7, pp. 481-498.

Lausmaa, R. 1983. Looduskaitse lühiajalise puhkuse veetmise aladel. [Conservancy in the Areas of Short Vacation.] In: Endel Varep (ed.) Looduskaitse ja puhkus. Tallinn: Valgus, pp. 29-35.

LFRL 2015 = Elust, usust ja usuelust 2015. [On Life, Faith, and Religious Life 2015.] Survey database owned by the Estonian Council of Churches. Survey conducted by the Social and Market Research Company Saar Poll OÜ in April-May 2015.

Lint, Aleksander 1938. Tähtvere park lindude pesitsuspaigana. [Tähtvere Park as a Nesting Area.] Loodusevaatleja: Populaar-loodusteaduslik ajakiri, No. 4-5, pp. 110-111. Available at https://www.digar.ee/arhiiv/et/perioodika/123687, last accessed on 18 December 2020. 
Loorits, Oskar 1932. Eesti rahvausundi maailmavaade. [The Worldview of Estonian Religion.] Tartu: Eesti Kirjanduse Selts.

Loorits, Oskar 1939. Oma rada: Programmartikleid uue Eesti loomisel 1934-1938. [Own Way: Programmatic Articles on Building the New Estonia 1934-1938.] Tallinn: Kuldkiri.

Loorits, Oskar 1941. Endis-Eesti elu-olu II. Lugemispalu metsaelust ja jahindusest. [Life in Estonia in the Past. Readings on Life in the Forest and Hunting.] Tartu: Teaduslik Kirjandus. Available at http://www.folklore.ee/rl/pubte/ee/eluolu/elu2/, last accessed on 18 December 2020.

Malloy, Tove H. 2009. Minority Environmentalism and Eco-Nationalism in the Baltics: Green Citizenship in the Making? Journal of Baltic Studies, Vol. 40, No. 3, pp. 375-395. https://doi.org/10.1080/01629770903086269.

Margus, M. 1983. Puhkemetsad Eestis. [Recreational Forests in Estonia.] In: Endel Varep (ed.) Looduskaitse ja puhkus. Tallinn: Valgus, pp. 98-107.

Mathiesen, A. 1937. Looduskaitse Eestis. [Conservancy in Estonia.] In: T. Lippmaa \& A. Mathiesen \& P. Päts \& G. Vilbaste (eds.) Looduskaitse I. Tallinn: Riigiparkide Valitsuse Kirjastus, pp. 12-20.

Merkel, Garlieb Helwig 1798. Die Vorzeit Lieflands: Ein Denkmal des Pfaffen- und Rittergeistes. Band I. Berlin: Vossischen Buchhandlung. Available at http://dspace. ut.ee/handle/10062/2908?locale-attribute=de, last accessed on 18 December 2020.

Mikita, Valdur 2015. Lindvistika ehk metsa see lingvistika. [Birdistics, or Get Lost, Linguistics.] N.p.: Välgi metsad.

Morden, Michael 2016. Anatomy of the National Myth: Archetypes and Narrative in the Study of Nationalism. Nations and Nationalism, Vol. 22, No. 3, pp. 447-464. https://doi.org/10.1111/nana.12167.

Mõttekiir 1988 = Mõttekiir. Eestlased kui metsarahvas. Mets vene muinasjuttudes. [Estonians as Forest People. Forest in Russian Fairy Tales.] ERR, 13 December. Available at https://arhiiv.err.ee/vaata/mottekiir-mottekiir-eestlased-kuimetsarahvas-mets-vene-muinasjuttudes, last accessed on 16 December 2020.

Ohlsson, Henrik 2020. Att närma sig en återbesjälad natur: Om helighet och ritualiseringar i terapeutisk naturkontakt. [Approaching the Resurrected Nature: About Holiness and Ritualisations in Therapeutic Contact with Nature.] In: Daniel Lindmark \& Anders Persson (eds.) Rituella rum och heliga platser: Historiska, samtida och litterära studier. Studies on the Religious History of the North 3. Skellefteå: Artos \& Norma, pp. 159-187.

Palm, A. 1983. Puhkuse veetmine vabariigis ja selle mõju loodusele. [Vacation in the Republic and Its Influence on the Nature.] In: Endel Varep (ed.) Looduskaitse ja puhkus. Tallinn: Valgus, p. 28.

Peegel, Juhan \& Aru, Krista \& Issakov, Sergei \& Jansen, Ea \& Lauk, Epp (eds.) 1994. Eesti ajakirjanduse teed ja ristteed: Eesti ajakirjanduse arengust (XVII sajandist $X X$ sajandini). [The Crossroads of Estonian Journalism: Development of Estonian Journalism (from the 17 th to the 20th Century).] Tartu: Tartu Ülikool \& Tallinn: Olion.

Pickel, Gert \& Pollack, Detlef \& Müller, Olaf 2012. Differentiated Secularization in Europe: Comparative Results. In: Detlef Pollack \& Olaf Müller \& Gert Pickel 
(eds.) The Social Significance of Religion in the Enlarged Europe: Secularization, Individualization and Pluralization. Farnham: Ashgate Publishing Ltd., pp. 229 256.

Plath, Ulrike 2008. Euroopa viimased metslased: eestlased Saksa koloniaaldiskursis 1770-1870. [The Last Savages in Europe: Estonians in German Colonial Discourse 1770-1870.] In: Rein Undusk (ed.) Rahvuskultuur ja tema teised. Tallinn: Underi ja Tuglase Kirjanduskeskus, pp. 37-65. Available at https://www.etis.ee/ Portal/Publications/Display/fecec8ba-9028-4478-8ea4-1c3d17f3f2de, last accessed on 18 December 2020.

Ranniku, Veljo 1976. Turist kaitsealadel. [Tourist and the Areas of Conservancy.] Eesti Loodus, No. 5, pp. 285-289. Available at https://www.digar.ee/arhiiv/et/ perioodika/92015, last accessed on 18 December 2020.

Reim, Paul 1940. Metsade rahvamajanduslik tähtsus. [The Economic Importance of Forests.] Eesti Metsaühingute Liit 1930-1940. Tallinn: Eesti Metsaühingute Liit, pp. 95-114.

Relve, Henrik 1982a. Hiiemets. [Sacred Forest.] Eesti Loodus, No. 5, pp. 308-314. Available at https://www.digar.ee/arhiiv/et/perioodika/92263, last accessed on 18 December 2020.

Relve, Henrik 1982b. Mets linlase pilguga. [Forest Through the Eyes of a City Dweller.] Eesti Loodus, No. 4, pp. 228-234. Available at https://www.digar.ee/arhiiv/et/ perioodika/92267, last accessed on 18 December 2020.

Remmel, Atko 2016. Ambiguous Atheism: The Impact of Political Changes on the Meaning and Reception of Atheism in Estonia. In: Roberto Cipriani \& Franco Garelli (eds.) Annual Review of the Sociology of Religion. Vol. 7: Sociology and Atheism, pp. 233-250. https://doi.org/10.1163/9789004319301_013.

Remmel, Atko 2019. Religiooni uurimisest ilmalikus ühiskonnas. [On Studying Religion in Secular Society.] Usuteaduslik Ajakiri, No. 3, pp. 95-126. Available at https:// usuteadus.ee/?page_id=1133\&lang=et, last accessed on 18 December 2020.

RTE $2014=$ Religioossed suundumused Eestis 2014. [Religious Trends in Estonia 2014.] The questionnaire was created by Lea Altnurme, survey conducted by the Social and Market Research Company EMOR in January-February 2014. Unpublished.

Seidra, V. 1938. Rahvaparkide arhitektoonilisest ilmest. [Architectonical Image of National Parks.] Eesti Looduskaitse, No. 3, pp. 77-80. Available at https://www. digar.ee/arhiiv/et/perioodika/114705, last accessed on 18 December 2020.

Selart, Anti 2014. Germanofoobist ökoprohvetiks: Oskar Loorits ja rikutud eestlased. [From Germanophobe to Eco-Prophet: Oskar Loorits and Spoiled Estonians.] Vikerkaar, No. 7-8, pp. 138-157. Available at https://www.digar.ee/arhiiv/et/ perioodika/35138, last accessed on 18 December 2020.

Servinski, Mihkel \& Kivilaid, Marika \& Tischler, Greta 2018. Eesti Vabariik 100: Statistiline album. [Republic of Estonia 100: Statistical Album.] Tallinn: Statistikaamet. Available at https://www.digar.ee/arhiiv/et/raamatud/132306, last accessed on 18 December 2020.

SFMC 2018 = RMK aastaraamat 2018. [SFMC Yearbook 2018.] E-publication. Available at https://media.rmk.ee/files/RMK_Aastaraamat_2018_EST.pdf, last accessed on 17 December 2020. 
Sikk, K. 1932. Me laulumehed oleme.... [We Are Singers...] In: Karl Verberg (ed.) Eesti Metsanduse aastaraamat VI. Tartu: Akadeemiline Metsaselts, pp. 393-396.

Soots, Ülo 1991. Eelistagem vaatlejaid küttidele. [Let's Prefer Observers to Hunters.] Eesti Loodus, No. 5, pp. 279-282. Available at https://www.digar.ee/arhiiv/et/ perioodika/92401, last accessed on 18 December 2020.

Statistics Estonia 2020 = Statistical database of registered vehicles. Available at https:// andmed.stat.ee/et/stat/majandus__transport__registreeritud-liiklusvahendid/ TS32/table/tableViewLayout1, last accessed on 16 December 2020.

Suur, A. 1938. Loodushoiu ja turismi-instituudi tegevusest ja põhimõtetest. [The Principles and Activities of the Institute of Nature Preservation and Tourism.] Eesti Looduskaitse, No. 2, pp. 40-43. Available at https://www.digar.ee/arhiiv/ et/perioodika/114697, last accessed on 18 December 2020.

Tamm, Marek 2008. History as Cultural Memory: Mnemohistory and the Construction of the Estonian Nation. Journal of Baltic Studies, Vol. 39, No. 4, pp. 499-516. https://doi.org/10.1080/01629770802468865.

Tammsaare, Anton Hansen 1981 [1926]. Tõde ja Õigus. [Truth and Justice.] Vol. 1. Tallinn: Eesti Raamat.

Thurfjell, David 2020. Granskogsfolk: hur naturen blev svenskarnas religion. [Spruce Forest People: How Nature Became the Swedes' Religion.] Stockholm: Norstedts.

Tüür, Kadri \& Maran, Timo 2005. Eesti looduskirjanduse lugu. [The History of Estonian Nature Writing.] In: Timo Maran \& Kadri Tüür (comps.) Eesti Looduskultuur: artiklikogumik. Eesti kultuuriloo ja folkloristika keskuse aastaraamat. Tartu: Eesti Kirjandusmuuseum, pp. 237-270.

Valk, Ülo 2005. Eesti rahvaluule loodusnägemused. [Visions of Nature in Estonian Folklore.] In: Timo Maran \& Kadri Tüür (eds.) Eesti looduskultuur: artiklikogumik. Eesti kultuuriloo ja folkloristika keskuse aastaraamat. Tartu: Eesti Kirjandusmuuseum, pp. 29-54.

Varep, Endel 1983. Eesti puhkekohad ajaloolis-geograafilisest aspektist. [Estonian Vacation Places from a Historical-Geographical Aspect.] In: Endel Varep (ed.) Looduskaitse ja puhkus. Tallinn: Valgus, pp. 7-17.

Västrik, Ergo-Hart 2015. In Search of Genuine Religion: The Contemporary Estonian Maausulised Movement and Nationalist Discourse. In: Kathryn Rountree (ed.) Contemporary Pagan and Native Faith Movements in Europe: Colonialist and Nationalist Impulses. New York \& Oxford: Berghahn, pp. 130-153.

Viator 1936. Vanu puid Kahkvas. [Old Trees in Kahkva.] Loodusevaatleja, No. 2, pp. 3840. Available at http://193.40.192.80/arhiiv/et/perioodika/123667, last accessed on 18 December 2020.

Viires, Ants 1970. Mets eesti talurahva elus. [Forest in the Lives of Estonian Peasants.] Eesti Loodus, No. 3, pp. 147-152. Available at https://www.digar.ee/arhiiv/et/ perioodika/92152, last accessed on 18 December 2020.

Viires, Ants 1975. Puud ja inimesed: puude osast Eesti rahvuskultuuris. [Trees and People: On the Role of Trees in Estonian National Culture.] Tallinn: Valgus.

Vilde, Eduard 1913. Pisuhänd: kolme waatusega lõbumäng. [Pisuhänd: A Comedy in Three Acts.] Tallinn: Maa. Available at https://www.digar.ee/arhiiv/et/ raamatud/13178, last accessed on 18 December 2020. 
Virumaa Teataja 1929. Jüriöö mälestamine hiiemäel. [Commemoration of St. John's Night at Sacred Hill.] Virumaa Teataja, No. 50, 7 May, p. 2. Available at https:// dea.digar.ee/cgi-bin/dea?a=d\&d=virumaavana19290507.1.4, last accessed on 18 December 2020.

Zechner, Johannes 2011. Politicized Timber: Imagined Landscapes of the German Forest 1800-1945. The Brock Review, Vol. 11, No. 2, pp. 19-32. https://doi.org/10.26522/ br.v11i2.315.

Atko Remmel is Associate Professor (PhD) at the University of Tartu and at Tallinn University, Estonia. He has published on the Soviet antireligious policy and atheist propaganda, secularization and religious change, and contemporary forms of (non)religion and spirituality. He has carried out fieldwork among nonreligious population in Estonia and on Estonians' relationship with nature.

atko.remmel@ut.ee

Tõnno Jonuks is Research Professor $(\mathrm{PhD})$ at the Estonian Literary Museum and Research Fellow at Tallinn University. His main research concerns Estonian religion in the past, material sources of religion, and animal symbolism in Estonia.

tonno.jonuks@folklore.ee 